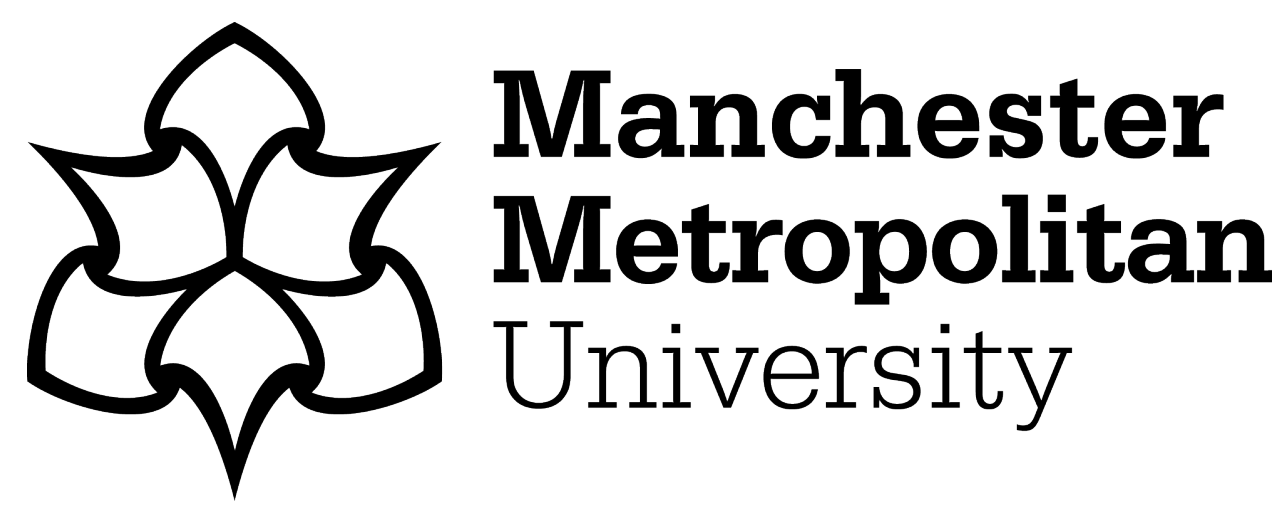

Filho, Walter Leal, Skanavis, Constantina, Kounani, Aristea, Brandli, Luciana Londero, Shiel, Chris, Paço, Arminda do, Pace, Paul, Mifsud, Mark, Beynaghi, Ali, Price, Elizabeth ORCID logoORCID: https://orcid.org/0000-00025723-7856, Salvia, Amanda Lange, Will, Markus and Shula, Kalterina (2019) The role of planning in implementing sustainable development in a higher education context. Journal of Cleaner Production, 235. pp. 678-687. ISSN 0959-6526

Downloaded from: https://e-space.mmu.ac.uk/623337/

Version: Accepted Version

Publisher: Elsevier BV

DOI: https://doi.org/10.1016/j.jclepro.2019.06.322

Usage rights: Creative Commons: Attribution-Noncommercial-No Derivative Works 4.0

Please cite the published version 
Manuscript Number: JCLEPRO-D-19-02807R2

Title: The Role of Planning in Implementing Sustainable Development in a Higher Education Context

Article Type: Original article

Keywords: Sustainable Development; Higher Education; Strategic Sustainability Planning; Implementation of Sustainability Plans

Corresponding Author: Ms. Amanda Lange Salvia,

Corresponding Author's Institution: Hamburg University of Applied Sciences

First Author: Walter Leal Filho

Order of Authors: Walter Leal Filho; Constantina Skanavis; Aristea Kounani; Luciana L Brandli; Chris Shiel; Arminda do Paço; Paul Pace; Mark Mifsud; Ali Beynaghi; Elisabeth Price; Amanda Lange Salvia; Markus Will; Kalterina Shulla

Abstract: The implementation of sustainable development in higher education is an important goal, and one which requires much planning. The many recurring problems and barriers that hinder the attainment of sustainable development objectives at universities are either directly or indirectly related to deficiencies in planning which pose a significant barrier to the implementation of sustainable development. There is therefore a perceived need to foster a better understanding of how planning may help higher education institutions to become more successful in implementing sustainable development. Based on this need, this paper describes the role of planning as a tool for improved knowledge and sound decision-making towards a better understanding of sustainability in a science and technology context, and the motivation towards transformation. In particular, it reports on a survey in the context of which some of the major obstacles for planning and implementing sustainable development at universities are outlined. The study identified the fact that many universities are yet to have fully developed plans to take into account matters related to sustainable development, and describes some the elements which could be considered in attempts to give a greater emphasis to sustainability to planning in a higher education context. 


\section{Cover Letter}

Dear Editor,

I am pleased to submit the revised version of the paper titled "The Role of Planning in Implementing Sustainable Development in a Higher Education Context".

We hope we could meet the reviewers' expectations and that it is now suitable for Journal of Cleaner Production.

Thank you.

Sincerely yours,

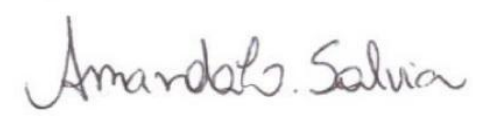

Amanda Lange Salvia on behalf of the authors

Graduate Program in Civil and Environmental Engineering

University of Passo Fundo

BR 285, São José | Passo Fundo/RS | CEP: 99052-900 / +55 5433168203

Brazil

e-mail: amandasalvia@gmail.com 


\section{The Role of Planning in Implementing Sustainable Development in a Higher Education Context}

\section{Walter Leal Filho ${ }^{a}$, Constantina Skanavis ${ }^{\mathrm{b}}$, Aristea Kounanic ${ }^{\mathrm{c}}$, Luciana Londero Brandli ${ }^{\mathrm{d}}$, Chris Shiel $^{\mathrm{e}}$, Arminda do Paço ${ }^{\mathrm{f}}$, Paul Pace ${ }^{\mathrm{g}}$, Mark Mifsud ${ }^{\mathrm{g}}$, Ali Beynaghi ${ }^{\mathrm{h}}$, Elisabeth Price $^{\mathrm{i}}$, Amanda Lange Salvia ${ }^{\mathrm{d}^{*}}$, Markus Will ${ }^{\mathrm{j}}$, Kalterina Shula ${ }^{\mathrm{k}}$}

${ }^{a}$ European School of Sustainability Science and Research, Hamburg University of Applied Sciences, Ulmenliet 20, D-21033 Hamburg, Germany. E-mail: walter.leal2@haw-hamburg.de

${ }^{\mathrm{b}}$ Research Center of Environmental Communication and Education. Department of Environment University of the Aegean. University Hill Mytilene, 81100 Greece E-mail: cskanav@aegean.gr

${ }^{\mathrm{c}}$ Research Center of Environmental Communication and Education. Department of Environment University of the Aegean. University Hill. Mytilene, 81100. Greece. E-mail: kounani@env.aegean.gr

${ }^{\mathrm{d}}$ University of Passo Fundo, Graduate Program in Civil and Environmental Engineering, Km 171, BR 285, Passo Fundo/RS, Brazil. E-mail: brandli@upf.br, amandasalvia@gmail.com (*corresponding author)

${ }^{\mathrm{e}}$ University of Bournemouth, Christchurch House C212, Talbot Campus, Fern Barrow, Poole, BH12 5BB, UK. E-mail: cshiel@bournemouth.ac.uk

${ }^{\mathrm{f}}$ Department of Management and Economics, Research Unit NECE, University of Beira Interior, Estrada do Sineiro, 6200-209 Covilhã, Portugal. E-mail: apaco@ubi.pt

${ }^{\mathrm{g}}$ Centre for Environmental Education \& Research, University of Malta, Msida MSD 2080, Malta. E-mail: paul.j.pace@um.edu.mt, mark.c.mifsud@um.edu.mt

${ }^{\mathrm{h}}$ Office of Sustainability, Amirkabir University of Technology, Tehran, Iran. Email: a.beynaghi@gmail.com

${ }^{\mathrm{i}}$ School of Science and the Environment. Manchester Metropolitan University. All Saints Building. Oxford Road. Manchester M15 6BH, UK. E-mail: e.price@mmu.ac.uk

${ }^{j}$ University of Applied Sciences Zittau/Görlitz, Theodor-Körner-Allee 16, 02763 Zittau. E-Mail: m.will@hszg.de

${ }^{\mathrm{k}}$ ZEF, Center for Development Research, University of Bonn, Genscherallee 3, 53113 Bonn. E-mail: kalterina@yahoo.co.uk 


\section{Highlights}

- Planning can assist in the implementation of sustainable development in higher education;

- Globally, the development of sustainability initiatives in universities varies among institutions and regions;

- Institutional commitment is required, along with transformation of perceptions and use of interrelated perspectives;

- It is necessary to foster a better understanding of how planning may help universities to implement sustainability. 


\title{
The Role of Planning in Implementing Sustainable Development in a Higher Education Context
}

\begin{abstract}
The implementation of sustainable development in higher education is an important goal, and one which requires much planning. The many recurring problems and barriers that hinder the attainment of sustainable development objectives at universities are either directly or indirectly related to deficiencies in planning which pose a significant barrier to the implementation of sustainable development. There is therefore a perceived need to foster a better understanding of how planning may help higher education institutions to become more successful in implementing sustainable development. Based on this need, this paper describes the role of planning as a tool for improved knowledge and sound decision-making towards a better understanding of sustainability in a science and technology context, and the motivation towards transformation. In particular, it reports on a survey in the context of which some of the major obstacles for planning and implementing sustainable development at universities are outlined. The study identified the fact that many universities are yet to have fully developed plans to take into account matters related to sustainable development, and describes some the elements which could be considered in attempts to give a greater emphasis to sustainability to planning in a higher education context.
\end{abstract}

Keywords: Sustainable Development, Higher Education, Strategic Sustainability Planning, Implementation of Sustainability Plans

\section{Introduction: planning for sustainable development}

Planning is seen as one of the keys for the successful implementation of sustainable development. Indeed, as the world now moves towards implementing the 2030 global agenda, proper planning has become highly relevant. HEIs need to participate in sustainable development practices, having education, research, internal management (operations) and community engagement (outreach) as main areas of study and development.

Apart from proper planning, the implementation of a successful sustainability strategy is dependent on a wide range of elements which include infrastructure, competence, and capacity building, among many others. According to experts, a sustainability strategy is characterized by a five-stage process: Assessment, Planning, Implementation, Evaluation, and Reassessment/Modification (Johnson et al., 2004). 
A sustainability planning procedure, i.e a procedure which may assist in implementing

sustainability-related efforts, should be carefully addressed from a variety of perspectives (Berke and Conroy, 2000) thus ensuring integrated processes (Wright, 2006). Planners need to conceive ways to concretely implement policy and solutions, and to carefully assess the links between efforts for the implementation of plans and the sustainability of its outcomes.

Universities play a vital role in sustainable development from various perspectives. For instance, they must support education for sustainable development (Disterhef et al., 2015; Brusca et al., 2018) and introduce active policies for attaining this goal (Lozano et al., 2015). In this context, numerous HEIs have been integrating environmental education and education for sustainable development (ESD) into their system, making SD an essential part of the institutional framework (Ramos et al., 2015), collaborating with other higher educational institutions (Lozano et al., 2013a), encouraging on-campus sustainability life experiences and improvements in the curriculum (Cortese, 2003), and 'Educating-the-Educators' programmes (Lozano et al., 2013b). It is undisputed that strategic planning is critical for all these aspects. This is so for various reasons: firstly, for setting organizational goals and objectives, secondly, for providing management with the essential guidance and lastly, for operating the institution effectively and efficiently. Strategic planning is also instrumental to the organization's continuous improvement and sustainability actions. Higher education has been using strategic planning and continuous improvement techniques, some adopted from industry. However, the contingent lack of understanding of strategic planning techniques could be a significant obstacle to sustainable development (Gordon and Fischer, 2015).

Several researchers have proposed a diversity of methods to incorporate sustainability into higher education (Rusinko, 2010) or into university curricula by proposing new courses (Bremer and Lopez-Franco, 2006; Pappas et al., 2013), models for evaluation (Watson et al., 2013; Savelyeva and McKenna, 2011) or manual on how to integrate SD and curricula (Ceulemans and De Prins, 2010), while others have recommended a complete restructuring of universities to tackle 
this challenge (e.g., Aktas et al., 2015; Leal Filho et al., 2017a; Leal Filho et al., 2017b). Planning

is an essential feature of all of them.

Based on the given background, the aim of this research paper is to describe the extent to which planning is being deployed as a tool for an inclusion of matters related to sustainable development in university programmes. It also outlines by means of a survey some of the major obstacles for planning and implementing sustainable development at higher educational institutions and designates the elements which may lead to a better accomplishment of the goals of planning.

\section{Advantages of planning for sustainable development}

With the caveat that planning involves a "calculating style of management" rather than a 'committing' (Mintzberg, 1989) which for many, may seem less appropriate for the commitment required for a broad vision of sustainability, it is evident that those universities at the forefront of integrating sustainable development across their operations (curriculum, campus, research and community), deploy planning processes to achieve their vision. Framing sustainable development as an opportunity rather than a problem, planning accordingly, with actions focused on economic, environmental, and social gains offers great potential and may ensure the future growth and health of higher education institutions (Burrell et al., 2011).

They will gain further advantage as they become more attractive to prospective students who want universities to take their environmental responsibilities seriously (NUS, 2015); they may reduce their costs and enhance their capitals.

Implementing sustainable development, a ‘wicked problem’ (Rittel and Webber, 1973), and a complex one (Leal Filho et al., 2018), may require a radical rethink of strategies and management within higher education (Shiel and Jones, 2016) but experience has shown that, despite the hurdles, developing a vision and strategy, articulating action plans, considering 
approaches to change, with detailed project planning, builds momentum for a more sustainable university and brings advantages.

Advantages will be greater where a balanced, holistic approach to sustainability guides development and approaches to planning are re-evaluated. Berke and Conroy (2000) suggest that too often, plans reviewed in their study did not exemplify a balanced, holistic approach. Further, planning educators and professionals need to adopt an expanded view of comprehensive planning. Planning theory is certainly relevant to sustainable development (Roseland, 2000) and specific areas, for instance in sustainable waste management (Hacking and Flynn, 2017). In both cases, but planners need to find inspiration from "greener pastures" and other theoretical domains.

Planning for sustainable development requires, as its starting point, a "vision of how things might be changed for the better, and a design or strategy for moving towards that vision" (Sterling and Maxey, 2013). The vision itself may transform and animate (Bennis and Nanus, 1985) the very act of bringing stakeholders together to articulate such a vision, extend knowledge about sustainability and serve to build commitment at the start of the journey. The process surfaces understandings and world-views, reveals the extent of commitment/or not, and draws stakeholders together to align with a common intent for planning purposes. If those leading the change have already undertaken preliminary analysis of the current situation, using conventional planning tools (e.g. opportunities and threats - SWOT and PESTLE, etc.) and have planned on the basis of information gathered and analysis, then evidence suggests (see Shiel, 2007) that they will have the advantage of being able to persuade and influence direction. They will also have the advantage of a clearer picture of the starting point, as a basis to coordinate actions going forward and to monitor progress. 
Figure 1: An Overview of a Planning and Implementation Process

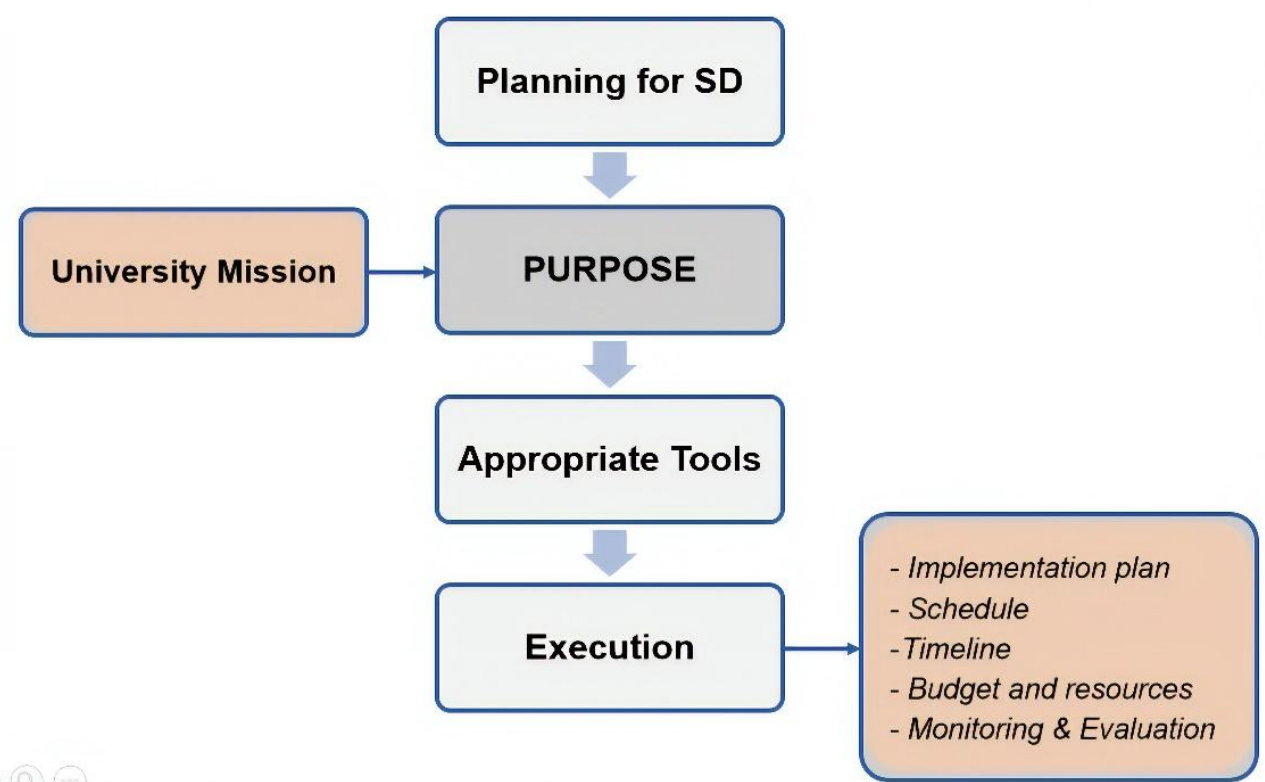

Source: authors.

Figure 1 represents a generic process deployed in university strategic planning with the key difference that SD has become the driving factor rather than something that is second-order to mission in planning.

Planning for SD will naturally begin in the context of the university mission, but in developing purpose, a complete rethinking and re-articulation of vision and mission may be vital to achieve SD outcomes. Once the institution has agreed on purpose, the planning tools to enable SD goals to be achieved can be selected; and then the execution will require developing the process that Figure 1 describes. It is important to build from the tools already available and seek further advantages through innovation and new planning methodologies appropriate for sustainable development, and for a future that is uncertain. Effective strategies for participation of all stakeholders in the planning stages enable local knowledge to be incorporated into plans and participants can develop new ways of thinking (Tippett et al., 2007). Sustainable development and action planning require participation and consensus which places new demands on existing governance and planning networks (Benneworth and Hospers, 2007). 
The use of tools, which by their very nature require an honest strategic appraisal of the

universities' strengths, weaknesses, opportunities, threats and organizational analysis of political, economic, social, and technological factors, will result in new learning. Another requirement is the understanding of how these variables can influence strategy development and implementation (Mintzberg, 2008).

If the aim is to bring about lasting change for sustainable development, then change agents who take on board theories of change management and approaches to strategic planning, reap further advantages. Kanter et al. (1992), for example, suggest a number of stages in the change process that need to be planned and managed:

- Analyse the organization and its need for change

- Create a shared vision and a common direction

- Separate from the past

- Create a sense of urgency

- Support a strong leader role

- Line up political sponsorship

- Craft an implementation plan

- Develop enabling structures

- Communicate, involve people and be honest

- Reinforce and institutionalise change

There are many other broadly similar approaches to consider, for example: Quinn (1980) offers an incremental approach (combining top-down with bottom-up) and where building understanding and support is critical for change but also important for sustainability; and Doppelt (2003) provides a "wheel of change toward sustainability" (Figure 2) which unlike other approaches does not follow a step-process. 


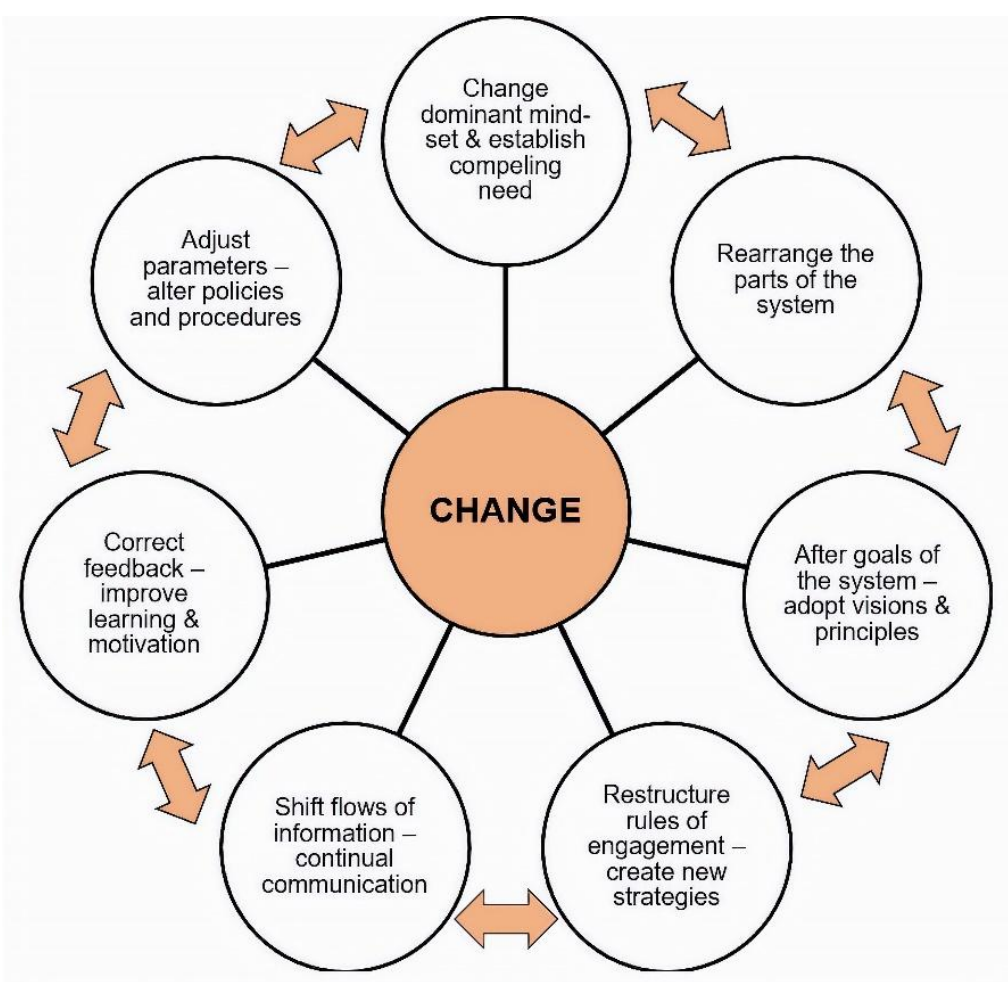

Source: Adapted from Doppelt (2003)

Each approach requires planning; choosing an approach, in the early stages, brings advantages in that a framework is provided for more detailed plans subsequently. There is no "one size fits all" approach; different approaches may suit different university contexts, cultures and the personal styles of individuals leading the planning, ranging from more top-down with tighter controls, to more emergent and less tightly managed. Such approaches have been applied successfully within the higher education context (see for example Marshall, 2007) to promote organisational change projects and planning processes.

Plans which flow from the overarching vision need to prioritise what needs to be done, potentially organised around themes (see Table 1 for an example). Some areas of sustainability in higher education (e.g. estates management) require more detailed planning and robust measures for control. More detailed planning needs to prioritise actions to raise standards and engagement from the very start. Starting from aspirations and visions, planning documents need to have tangible objectives, and concrete targets need to be established. 
Table 1: Possible components of a planning document

\begin{tabular}{lll}
\hline Theme: category & Aim & Action \\
\hline $\begin{array}{l}\text { Carbon footprint: } \\
\text { Institutional Level } \\
\text { Waste }\end{array}$ & $\begin{array}{l}\text { Promote waste } \\
\text { minimisation both within } \\
\text { the university and with } \\
\text { suppliers }\end{array}$ & $\begin{array}{l}\text { - Communication campaign to raise } \\
\text { awareness }\end{array}$ \\
& & $\begin{array}{c}\text { - Broaden focus to extend existing recycling } \\
\text { activity focused on staff to target students } \\
\text { - Introduce food waste bins }\end{array}$ \\
\hline Fairtrade & Achieve Fairtrade status & - Set up steering group \\
& & - Formulate policy \\
& & - Plan education programme \\
\hline Curriculum & Embed ESD & - Undertake benchmark study \\
& & - Rewrite curriculum guidelines \\
& & - Lead staff development \\
\hline $\begin{array}{l}\text { Carbon } \\
\text { footprint/Energy } \\
\text { Management }\end{array}$ & Reduce use of electricity & - Implement an Energy Management System \\
& & to ISO 50001 standard \\
\hline
\end{tabular}

The advantages of detailed action plans are clear, and may be summarised as follows:

- They demonstrate the institutional commitment;

- The goals and themes to be addressed are clearly set out;

- Specific actions to address the themes and achieve outcomes are articulated;

- Timelines and responsibilities are indicated;

- Clear targets and success criteria may enable an assessment of progress;

- Arrangements are specified for monitoring and reporting;

- Estimates may also be included of the staff time and resources needed to implement the plan enabling gaps to be identified.

However, Mintzberg (2008) cautions that a proper planning commits substantial organizational resources and human resources, and requires a great deal of engagement from stakeholders at all levels of the organisation.

In summary, if universities are to integrate sustainable development across their institutions, planning is essential to accrue long term advantages. Tools and techniques from strategic management and planning may be adopted and built upon. Further, planning for 
sustainable development may help a university identify savings and benefits throughout its

management and operations, and improve its functioning in the future. The triple bottom line incorporates an approach that allows an organisation to plan for the long-term in terms of health, savings and growth.

\section{Methodology used}

\subsection{Survey design}

Based on the need for studies specifically focusing on challenges to planning and implementing sustainability in higher education, a survey was designed and performed among a set of universities. It was guided by three main questions:

a) To which extent do universities consider sustainability planning?

b) What is the importance afforded to sustainability planning?

c) Are current structures and frameworks well developed?

In the initial stage, a list of items was developed then reviewed to remove overlap and to ensure that all relevant questions were considered. The survey was pre-tested and piloted prior to its deployment, using a panel of academics with responsibility for sustainability in different universities.

The survey was disseminated online with data gathered between $25^{\text {th }}$ September and $25^{\text {th }}$ October 2017 using SurveyMonkey. The survey instrument was composed of 9 questions (six closed questions and three open ended questions) and structured to elicit information on the lived experiences of the actual university the participants worked in. The questionnaire also collected sociodemographic characteristics of the university staff and eventually a number of questions examined amongst others: the importance the University attaches to issues of sustainable development, the resources afforded to the sustainability development team and the importance given to environmental sustainability policy and sustainable development. The respondents were asked to provide details on the issues and challenges they face to achieve sustainable development 
at their respective University together with approaches or solutions that specifically target such issues.

\subsection{Sampling}

The survey was sent to the following groups: rectors and office managers of a wide range of universities, including those which participated in the Green Sustainability Metrics 2016; authors of publications on the subject "sustainability at universities" in the Web of Science between 2007-2016; participants in the World Symposium on Sustainable Development at Universities, held in September 2016 at the Massachusetts Institute of Technology in the United States of America; representatives of universities (sustainability office managers, researchers/teachers) participating in the Inter-University Program for Sustainable Development Research (IUSDRP); representatives of the universities participating in the Copernicus Alliance; rectors and managers of the Sustainability Office of the Universities participating in the Association, for the Advancement of Sustainability in Higher Education (AACHE), as already proposed by other studies (Leal Filho et al., 2019). Thirty nine different higher education institutions from five continents participated in this study.

\subsection{Data analysis}

The numerical data collected from the 39 responses was inputted in SPSS and analysed through descriptive statistics. The three open ended questions formed a major part of the data collected and were analysed through content analysis to reveal a number of themes. The regional distribution of the respondents is showed in the Table 2 . 
Table 2 - Distribution of the respondents by Region

\begin{tabular}{lcc}
\hline Country & Frequency & Percent \\
\hline North America & 8 & 20.5 \\
Africa & 1 & 2.56 \\
Australasia & 2 & 5.12 \\
Europe & 19 & 48.71 \\
South America & 4 & 10.25 \\
Asia & 5 & 12.82 \\
\hline Total & 39 & 100.0 \\
\hline
\end{tabular}

\section{Results Presentation}

\subsection{Results from the Quantitative Analysis}

For the first question, on the importance afforded by universities to matters related to sustainable development there is an uneven spread in the responses with a noticeable skew to positive replies. In fact, the majority of responses (about 64\%) are of the opinion that their university affords importance to issues related to sustainable development. The results are illustrated in Table 3. As far as the regional distribution is concerned, universities in Europe and North America tend to strongly agree/agree with the statements made.

Table 3 - My University attaches a lot of importance to matters related to sustainable development.

\begin{tabular}{lcc}
\hline & Frequency & Percent \\
\hline 1 - Strongly Disagree & 0.0 & 0.0 \\
2 - Disagree & 10 & 25.6 \\
3 - Don't Know & 4 & 10.3 \\
4 - Agree & 18 & 46.2 \\
5 - Strongly agree & 7 & 17.9 \\
\hline Total & 39 & 100.0 \\
\hline
\end{tabular}

The results for the second question on the current development of the official policy or planning framework for implementing sustainable development at University indicate a broad range of responses from universities with nearly equal numbers agreeing or disagreeing with this statement. In fact, 43.6\% Disagree or Strongly Disagree while 46.2\% Agree or Strongly Agree. Very few $(10.3 \%)$ choose the neutral response 'I don't know'. The results are illustrated in Table 4. 
Table 4 - The official policy or planning framework for implementing sustainable development at your University is well developed.

\begin{tabular}{lcc}
\hline & Frequency & Percent \\
\hline 1 - Strongly disagree & 4 & 10.3 \\
2 - Disagree & 13 & 33.3 \\
3 - Don't know & 4 & 10.3 \\
4 - Agree & 17 & 43.6 \\
5 - Strongly agree & 1 & 2.6 \\
\hline Total & 39 & 100.0 \\
\hline
\end{tabular}

As far as the regional distribution is concerned, universities in Europe tend to strongly agree/agree with the statements made, where other regions have less strong views on the topic.

The large majority of respondents (66.7\%) are of the opinion that the person in charge of planning on matters related to sustainable development at their university is not afforded enough resources to work effectively. Only $20.5 \%$ of the respondents responded that these persons receive adequate resources. From comparing the results of Table 2, 3 and 4 it appears that there is more thrust to have published sustainability policies and framework and less enthusiasm to actually fund the initiatives pertaining to sustainable development at higher institutions. The results are illustrated in Table 5 .

Table 5 - The person in charge of planning on matters related to sustainable development at your university is afforded enough resources to work effectively.

\begin{tabular}{lcc}
\hline & Frequency & Percent \\
\hline 1 - Strongly disagree & 6 & 15.4 \\
2 - Disagree & 20 & 51.3 \\
3 - Don't know & 5 & 12.8 \\
4 - Agree & 6 & 15.4 \\
5 - Strongly agree & 2 & 5.1 \\
\hline Total & 39 & 100.0 \\
\hline
\end{tabular}

As far as the regional distribution is concerned, universities in Latin America and Africa tend to strongly disagree/disagree with the statements made. 
A very high percentage of respondents $(66.7 \%)$ are of the opinion that sustainable

development policies, procedures or activities are not properly implemented in teaching and research at their institution. Only $23.1 \%$ agree with this statement again illustrating a gap between what is said and written regarding sustainable development at such institutions and what is actually carried out.

Table 6 - Sustainable development policies, procedures or activities are properly implemented in teaching and research

\begin{tabular}{lcc}
\hline & Frequency & Percent \\
\hline 1 - Strongly disagree & 3 & 7.7 \\
2 - Disagree & 23 & 59.0 \\
3 - Don't know & 4 & 10.3 \\
4 - Agree & 8 & 20.5 \\
5 - Strongly agree & 1 & 2.6 \\
\hline Total & 39 & 100.0 \\
\hline
\end{tabular}

As far as the regional distribution is concerned, universities in all geographical regions indicated they strongly disagree/disagree with the statements made, which shows that proper provisions are yet to be made.

In the last question that focused on the monitoring and evaluation of achievement of outcomes in the sustainable development planning process, the results indicate a broad range of responses from universities with nearly equal numbers agreeing or disagreeing with this statement. In fact, 53.6\% Disagree or Strongly Disagree while 43.6\% Agree or Strongly Agree. Very few $(10.3 \%)$ choose the neutral response 'I don't know'. The results are illustrated in Table 7. 
Table 7 - Monitoring and evaluation of achievement of outcomes in your sustainable development planning process is carried out effectively.

\begin{tabular}{lcc}
\hline & Frequency & Percent \\
\hline 1 - Strongly disagree & 7 & 17.9 \\
2 - Disagree & 14 & 35.9 \\
3 - Don't know & 1 & 2.6 \\
4 - Agree & 15 & 38.5 \\
5 - Strongly agree & 2 & 5.1 \\
\hline Total & 39 & 100.0 \\
\hline
\end{tabular}

As far as the regional distribution is concerned, universities in Latin America and Africa tend to strongly disagree/disagree with the statements made.

\subsection{Results from the Qualitative Analysis}

In the open-ended questions, the responses were varied both according to context and individual - but a number of areas and trends emerged within each question.

\subsubsection{Problems related to Planning and Implementing Sustainable Development}

The first question asked the respondents to list the problems that hinder their university's plans to implement measures related to sustainable development. Each respondent could list more than one problem; therefore 50 responses were received. Most of them $(n=17$ responses) focused on finances and support as the following verbatim examples illustrate:

- Lack of funding and international collaboration.

- Money, different goals of different faculties.

- Lack of support from senior staff in leadership positions. Lack of financial resources.

- The main problem is a general lack of government funding for universities which places on-going financial constraints on what we can do. 
Other responses $(n=13)$ focused on lack of interest or conflicting interests and beliefs at

the senior level that have a negative effect on sustainable development at universities.

- Conflicting opinions at the senior level. A minority of students seem willing to support SD policies.

- Absence of vision, policies, and supporting framework - Little interest across the university, especially among administrators - Limited understanding of sustainability across the university.

- Some key senior managers are not yet convinced of the merits, particularly in the context of tight budgets. Also our student body manifests very limited interest and so the drive for change does not come from these key stakeholders either.

Some responses $(\mathrm{n}=11)$ focused on issues of different visions for universities and their existence.

- Focus on rankings related to official evaluation of research and teaching protocols.

- Lack of coherent vision for larger community. Efforts fractured and rudimentary.

- Lack of involvement of the university community. Absence of transfer of the habits from home (turn off lights, recycle, ...) to the University. Excessive use of private cars. Ancient infrastructures.

While other responses focused on the lack of knowledge and lack of capacity to carry out such initiatives $(\mathrm{n}=9)$ :

- Lack of know-how, lack of resources.

- Lack of knowledge and motivation by senior management - happy to do the minimum. 
- Lack of strategy and organized efforts at the level of entire university. Lack of

\subsubsection{Solving the problems related to Planning and Implementing Sustainable Development}

In the second question the respondents were asked to explain how their university has solved or is solving these problems. There were varied responses $(\mathrm{n}=31)$ but they can be grouped into one of three categories:

- Effective teamwork $(\mathrm{n}=21)$

- Collaboration with the outside community $(n=6)$

- More Effective Communication $(\mathrm{n}=4)$

Effective teamwork: When discussing teamwork universities mentioned the setting up of teams of people that aim to implement SD initiatives at the institution:

- A green team is officially working since December 2015, focusing on energy and buildings, mobility; wastelfood/water; urban outreach and green procurements. The team is working in connections with institution and student team. We use SDGs as metrics. We also refer to sustainable university campus networks.

- A group of academics have organised to push and implement curriculum innovations and high-profile events to highlight the significance of the sustainability agenda in 
education and other aspects of the operations and management. A cross sector group has also formed a steering group and sought a chair from the University's Executive Group, to increase the pressure on facilities and estates.

- Creating a group/commission of Social and Environmental Responsibility, but operative partially and nowadays in a pause situation.

Collaboration with the outside community: Collaboration with the outside community was mainly mentioned with reference to exchange programmes and local or city councils indicating willingness to collaborate but perhaps within a narrow range of possibilities:

- Access to grants for researcher in Sustainable Development and international exchange programmes because of collaboration with EU Units and EU grants.

- Collaboration with the City Council to increase public transport and bike path. Information and awareness campaigns to act sustainably. Compost, put LED bulbs and solar panels in new buildings.

More Effective Communication: More effective communication was mentioned especially with regard to raising awareness on achievements related to sustainable development, in order to foster better relations and also for information sharing.

- Trying to communicate achievements related to sustainable development initiatives to senior management, prioritising work, discussing challenges and potential consequences related to time and resources shortage.

- Continuing to develop relationships across campus units through communication with those who have the ability to advocate for an integrated approach that begins to model sustainable development at the campus level. 
- Continuous information sharing, increasing knowledge of personnel and students regarding $S D$, development of waste management plan and sustainable green areas management plan.

\subsubsection{Planning Tools and approaches to support Sustainable Development implementation \\ In the last open-ended question, the respondents were asked to list any planning} tools/approaches used by their university to support the implementation of the sustainable development policy or planning framework (total of 32 responses). The majority $(n=24)$ mentioned the setting up of a centre, course or process:

- A centre has been set up to steer the planning and implement a set of measures visa-vis a planning framework.

- We have a strategic plan till 2019. We are training professors from other faculties and research institutes. We have meetings on voluntary agreed activities once each two or three weeks where we monitor the efforts.

- ISO 14001 National Union of Students Responsible Futures.

- LiFE Index.

- Living Lab BREEAM suite of certification methods.

- Policy on Sustainable Development.

- Sustainability Committee; Sustainable Procurement Committee; Sustainable L\&T Group.

- The effort is campus focused and the campus is a member of AASHE which uses an evaluation rubric and reporting structure for campus only projects.

Other responses $(n=3)$ focused on the greening of the actual University curriculum.

- Encourage greening curriculum (like introduce a new transversal competence for all degrees) and an educational practice which entails sustained action Develop the 
capacity to work in intersubjective or transdisciplinary teams, to offer proposals

that contribute to a sustainable environmental, economic, political and social development. Provide courses for teacher training in this subject.

- Have our carbon reductions targets; Fairtrade procedures and targets, curriculum framework which incorporated education for sustainability principles, and periodic review processes which require course teams to indicate how they incorporate sustainability in revised and new courses.

- We combine two approaches to the curriculum development: we developed one masters' programme on Environment and Nature resource economics, underpinned by ideas of sustainability. In the same time, we complement the content of existing programmes by the courses on sustainability and bring a focus in the existing courses.

A number of respondents $(n=5)$ were not aware of any initiatives indicating a lack of communication within the University itself or a lack of goodwill from the University to implement change.

- Do not have any yet. Planning occurs within disciplinary silos.

- Don't know

- None at the university level. Due to the challenges of higher education transformation in past decades (related to the Bologna process as well as transition from post-socialist HE environment), the sustainability theme has been rather neglected so far.

- None to my idea

- Not sure 


\section{Discussions}

The opinion of the sample regarding the importance attached by universities to sustainable development is divided. This is not a novelty since across the years several institutions have been involved in sustainability initiatives, while others have been less active in the pursuit and implementation of measures related to sustainable development. This is partly because of the inadequacy of the support provided (Velazquez et al., 2006), but it could also reflect an inherent conviction that sustainable development is a fad (not a priority) and hence cannot be adequately addressed in their policies and programmes.

One example of initiative which may help adequately approach sustainability is the PRME (Principles for Responsible Management Education). By focusing on purpose, values, method, research, partnership and dialogue (PRME, 2018), this initiative aims at transforming academic institutions by adding values of sustainability and promoting a "true paradigm change", and not only "green touches". In order to succeed at this, real understanding about conceptual shifts and engagement are necessary (Alcaraz et al., 2011).

According to the opinion of the respondents, the official policy or planning framework for implementing sustainable development is well developed but just for half of the sample; nevertheless, the majority of the respondents thinks that there are not enough resources to that policy being implemented effectively. As stated in the literature, this implementation depends on a wide range of factors which include infrastructure, competence, resources, and capacity building (Johnson et al., 2004), and most of the times it is hard to combine all these conditions. The lack of awareness of the implications of sustainable development, and ESD in particular, further shackles implementation resulting in lack of planning characterised by sporadic initiatives that drain resources and fail to address issues holistically. Despite the fact that Green or Sustainability Offices at HEIs also report challenges related to lack of resources and administration support, their work structure (with sustainability coordinator or sustainability committees, for example) may 
greatly contribute to plan/execute projects or develop policy making in a strategic way (Leal Filho et al., 2019a).

Sustainable development policies, procedures or activities are not properly implemented in teaching and research at many of the sample institutions, which is contrary to the recommendations of Burrell et al. (2011). According to the authors, it is evident that universities at the forefront of integrating sustainable development across their main activities (teaching and researching) will also lead a successful planning process to reach that aim. One example from the engineering education shows that difficulties in planning the inclusion of sustainability in teaching directly affect the difficulties found in didactic practice afterwards (Rampasso et al., 2018). It implies that the difficulties concerning planning the implementation of SD in higher education need to be overcome in order to enable the successful practice of the university roles (teaching, research, among others).

This topic is a clear reflection of Orr's myths (a set of myths which try to explain why institutional engagement on sustainability can be limited at times) that purportedly plague the traditional educational structures of higher education institutions and consequently their inadequacy to address the challenges posed by ESD and develop professionals who are ecologically and socially sensitive and committed (and prepared) for change (Orr, 2004). This is further compounded by higher education institutions' reductive definition of knowledge and resultant emphasis on transmissive pedagogies rather than on transformative ones.

Most problems related to planning and implementing sustainable development are related to finances and lack of support and resources, as well as lack of interest or conflicting interests at the administration level, which is in line with Mintzberg (2008) concerns, recommending a great engagement from the elements at all levels of the organisation. Likewise, the poor knowledge of the strategic planning techniques can be also a significant barrier to sustainable development (Gordon and Fischer, 2015). However, these can just be the symptoms of a deeper root cause for these barriers to sustainable development implementation and university based ESD programmes. 
One such root cause is the monodisciplinary organisational structures of universities that

determine funding, result in territorial conflicts, limit student mobility from one area to another and generate competition at various levels (Moore, 2005).

The problems related to planning and implementing sustainable development can be solved by effective teamwork, collaboration with the outside community and more effective communication. This finding is supported by Kanter et al. (1992) which outline that a changing process needs to be planned and managed (being the communication and the involvement of people crucial for the success) and by Katiliūtè et al. (2014), who highlight the importance of universities taking more advantage of sustainability communication and dissemination. Leal Filho et al. (2019b) also mentioned the involvement of community stakeholders and internal and external communication as fundamental items for planning and implementing sustainability at HEIs.

Additionally, to foster a change to a new approach of sustainability at universities, community engagement must be considered (Roseland, 2000; Yanez et al., 2018). At this point it is relevant to stress the importance of actively involving the student community as the main change agents in any serious attempt at implementing sustainable development across higher education institutions (Ryan-Fogarty et al., 2016).

Although planning tools and approaches to support the sustainable development implementation can be specifically centred in a centre, course or process and in the university curriculum, they need to be owned, valorised and consequently supported by the whole institution. As stated by Neville et al. (2000), the curriculum development is considered crucial to disseminate the knowledge across the institutions, promote transformative pedagogies as well as the leadership skills that are critical to cultivate commitment towards an innovative sustainability process.

\section{Implications for theory and practice: Towards Better Planning and Implementation of} Sustainable Development in Higher Education 
The lessons learned are a summary of knowledge or understanding gained by the positive

and negative experiences on planning and implementing sustainable development from the universities reported in this research. The insights listed below can have relevance for other contexts and be replicable in other higher education institutions. Five insights could be identified:

(a) Limited awareness and understanding about sustainability and low importance afforded to SD matters. Universities need to go beyond the simple academic treatment of issues related to SD and identify ways how SD should impact the 'day-to-day functioning' at the individual, departmental and institutional levels. Nevertheless, the number of universities that have already developed their respective SD plans is increasing. However, in most of the cases, these strategies betray a limited understanding of sustainability, a high degree of institutional insularity and low knowhow on how to effectively transform university practices, in line with the results found by Ávila et al. (2017). To resolve this issue, universities need to develop partnerships with other universities or engage in international programs with the purpose of consolidating and further developing their know-how about sustainable development implementation strategies.

(b) Lack of an official body responsible for SD implementation. The successful implementation of a SD strategy necessitates the setting up of a body responsible for its Assessment, Planning, Implementation, Evaluation, and Reassessment (i.e. the five-step process proposed by Johnson et al., 2004). This official body is a tangible indicator of the university's support and commitment towards significant progress in advancing sustainability on campus.

(c) Not all universities have a planning framework supporting the SD implementation. Investing in a planning framework is necessary in order to engage all members of the 
academic community and the student body, and to address areas where sustainability efforts

are needed in the short, medium and long term. The planning framework ensures wellarticulated actions with specific outcomes, timelines, responsibilities, defined targets and the wise use of resources. The planning framework needs to be re-evaluated and updated regularly to ensure its continued relevance to the emergent needs of the university's community. Moreover, to ensure a wide ownership (and commitment), the framework needs to be developed, implemented, monitored and evaluated by the entire university community.

(d) Resources for implementation SD are not enough. Resources are essential to the successful implementation of SD in universities and perhaps one of the key challenges. University rectors and finance office managers must be aware that the initial costs in SD will be paid off by savings at later stages. As Leal Filho (2015) comments, universities investing in campuswide waste prevention and energy conservation schemes will promptly reduce the costs associated with waste disposal and lower energy bills often in the medium term. To obtain resources, universities could develop collaborations with the outside community, through the access to SD research grants and more efforts in entrepreneurship and public-private partnerships.

(e) More effective communication. Communication is essential to facilitate the participation of all the university community - particularly the student population - in activities and decisions related to SD. Besides making policies understandable and meaningful, a strong communication network fosters ownership and acceptance of the university's SD strategy. This can be achieved by ensuring that the communication is not one-way (i.e. just informative) and empowering (i.e. providing the tools for individuals to become effective change agents). 
Figure 3 summarizes the main points outlined above that should be considered to attain

better planning and implementation of sustainable development in higher education institutions.

Figure 3 - Main Points Towards Better Planning and Implementation of SD in HEIs.

\section{$\mathrm{HEl}$ engagement}

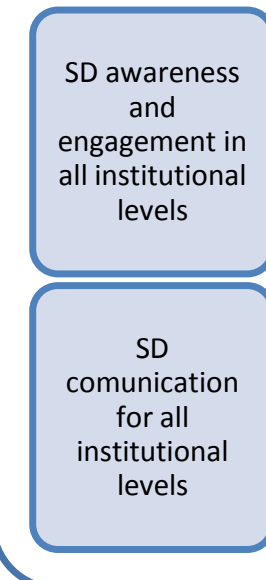

\section{HEI Support}

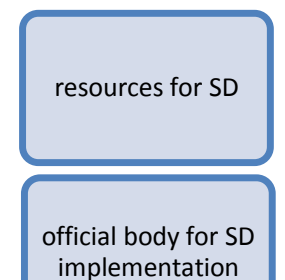

\section{Planning framework}

implementation

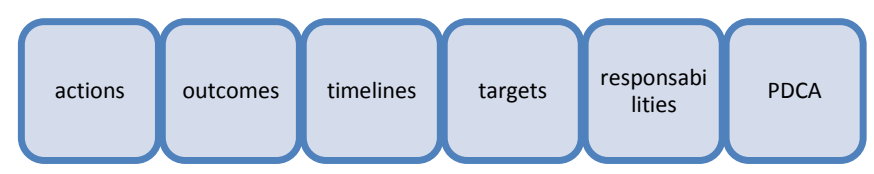

Their holistic consideration can ensure that not solely a better planning but also the subsequent implementation - and planned reforms - may be more easily implemented.

\section{Conclusions}

This paper has demonstrated the importance of planning for the further implementation of sustainable development in higher education, and has outlined some of the problems that have presented progress. The size of the sample of this study presents a limitation as it does not allow an extrapolation of its findings to all universities. However, the results gathered offer an overview of the issues at hand.

The first one is that the perception of universities in respect of the implementation of sustainability in these institutions need to be radically transformed. But the transformation cannot be limited to curriculum changes, or that planning in the curriculum is only one element, albeit a very important one. Instead of planning of sustainability in a single area, there is a perceived need 
for multiple perspectives, so that social scientists, natural scientists and engineers equally feel they ought to engage, using their various educational backgrounds.

The second element is that we need to provide an interrelated, "whole systems" perspective to the planning and implementation of sustainable development, within which to consider the education and training of these same social scientists, natural scientists and engineers universities. After all, these future professionals will play a vital role in affecting environment and society.

Finally, there is a need to address a myth, namely that planning for the implementation of sustainable development at universities is too expensive. On the contrary, a good planning process takes special care of the economic aspects, and when properly implemented, capitalises on the potential synergies from the various university activities.

In summary, an intelligent approach to planning allows higher education institutions to benefit from the ecological, social and economic aspects of sustainable development, and make the most of their resources in implementing sustainability efforts.

Some elements may lead to a better accomplishment of planning sustainable development at university level: the first one is the engagement with the SD in all institutional levels which shall be improved by SD awareness and communication. The second point is the HEI support with specific resources and official body for SD implementation. The last element is a formal planning framework, with all actions, targets, outcomes, responsibilities, timelines and a management approach.

\section{Acknowledgments}

Regarding Arminda do Paço, the author received the support of FCT Foundation for Science and Technology - Project UID/GES/04630/2013.

Declarations of interest: none. 


\section{References}

Aktas, B. C., Whelan R., Stoffer H., Todd E., Kern L. C. (2015). Developing a university-wide course on sustainability: a critical evaluation of planning and implementation. Journal of Cleaner Production, 106, 216-221.

Alcaraz, J. M., Wiktoria Marcinkowska, M., Thiruvattal, E. (2011). The UN-principles for responsible management education: sharing (and evaluating) information on progress. Journal of Global Responsibility, 2(2), 151-169.

Ávila, L.V., Leal Filho, W., Brandli, L. L. MacGregor, C., Molthan-Hill, P., Özuyar, P. G., Moreira, R. M. (2017). Barriers to innovation and sustainability at universities around the world. Journal of Cleaner Production, 164, 1268-1278.

Benneworth, P., Hospers, G. J. (2007). Urban competitiveness in the knowledge economy: Universities as new planning animateurs. Progress in Planning, 67(2), 105-107.

Bennis, W., Nanus, B. (1985). Leadership: The strategies for taking charge. New York:Harper.Row, 35p.

Berke, R. P., Conroy, M. M. (2000). Are we planning for sustainable development?. Journal American Planning Association, 66(1), 21-33.

Bremer, M. H., López-Franco, R. (2006). Sustainable development: ten years of experience at ITESM's graduate level. Journal of Cleaner Production, 14(9-11), 952-957.

Brusca, I., Labrador, M., Larran, M. (2018). The challenge of sustainability and integrated reporting at universities: A case study. Journal of Cleaner Production, 188, 347-354

Burrell, D. N., Anderson, M., Bessette, D., Dawson, M. (2011). Contemporary evaluation of universities and sustainability strategic planning. Review of Management Innovation \& Creativity, 4(11), 65-80.

Ceulemans, K., De Prins, M. (2010). Teacher's manual and method for SD integration in curricula. Journal of Cleaner Production, 18(7), 645-651.

Cortese, A.D. (2003). The critical role of higher education in creating a sustainable future. Planning for Higher Education, 31(3), 15-22.

Doppelt, B. (2003). Leading change toward sustainability. Sheffield: Greenleaf Publishing.

Disterheft, A., Caeiro, S., Azeiteiro, U.M., Leal Filho, W. (2015). Sustainable universities: a study of critical success factors for participatory approaches. Journal of Cleaner Production, 106, 11-21.

Gordon, G., Fischer, M. (2015). Strategic planning in public higher education: Management tool or publicity platform. Educational Planning, 22(3), 5-17.

Hacking, H., Flynn, A. (2017). Networks, power and knowledge in the planning system: A case study of energy from waste. Progress in Planning, 113, 1-37. 
Johnson, K., Hays, C., Center, H., Daley, C. (2004). Building capacity and sustainable prevention innovations: a sustainability planning model. Evaluation and Program Planning, 27(2), 135-149.

Kanter, R. M., Stein, B. A., Jick, T. D. (1992). The challenge of organizational change. New York: The Free Press.

Katiliūtè, E., Daunorienè, A., \& Katkutè, J. (2014). Communicating the sustainability issues in higher education institutions World Wide Webs. Procedia-Social and Behavioral Sciences, 156, 106-110.

Leal Filho, W. (2015). Campus Greening: Why It Is Worth It. In: W., Leal Filho, N., Muthu, G., Edwin, \& M., Sima (Eds.). Implementing Campus Greening Initiatives. World Sustainability Serie: Springer International Publishing.

Leal Filho, W., Wu, Y. C. J., Brandli, L. L., Avila, L. V., Azeiteiro, U. M., Caeiro, S., Madruga, L. R. D. R. G. (2017a). Identifying and overcoming obstacles to the implementation of sustainable development at universities. Journal of Integrative Environmental Sciences, 14 (1), http://www.tandfonline.com/doi/full/10.1080/1943815X.2017.1362007.

Leal Filho, W., Brandli, L. L., Becker, D., Skanavis, C., Kounani, A., Sardi, C., Papaioannidou, D., Paço, A., Azeiteiro, U., Sousa, L. O., Raath, S., Pretorius, R., Shiel, C., Vargas, V., Trencher, G., Marans, R. W. (2017b). Sustainable Development Policies as Indicators and Pre-Conditions for Sustainability Efforts at Universities: fact or fiction? International Journal of Sustainability in Higher Education, 19(2), 85-113, https://doi.org/10.1108/IJSHE-01-2017-0002.

Leal Filho, W., Pallant, E., Enete, A., Richter B., Brandli, L. L. (2018). Planning and implementing sustainability in higher education institutions: an overview of the difficulties and potentials. International Journal of Sustainable Development \& World Ecology, 10.1080/13504509.2018.1461707 Leal Filho, W., Will, M., Salvia, A. L., Adomßent, M., Grahl, A., Spira, F. (2019a). The Role of Green and Sustainability Offices in Fostering Sustainability Efforts at Higher Education Institutions. Journal of Cleaner Production, https://doi.org/10.1016/j.jclepro.2019.05.273

Leal Filho, W., Skouloudis, A., Brandli, L. L., Salvia, A. L., Avila, L. V., Rayman-Bacchus, L. (2019b). Sustainability and Procurement Practices in Higher Education Institutions: Barriers and Drivers. Journal of Cleaner Production, https://doi.org/10.1016/j.jclepro.2019.05.202

Leal Filho, W.; Shiel, C.; Paço, A.; Mifsud, M.; Ávila, L.V.; Brandli, L.L.; Molthan-Hill, P.; Pace, P.; Azeiteiro U.M.; Vargas, V.R.; Caeiro S. (2019c). Sustainable Development Goals and sustainability teaching at universities: Falling behind or getting ahead of the pack? Journal of Cleaner Production, $232,285-294$.

Lozano, R., Ceulemans, K., Alonso-Almeida, M., Huisingh, D., Lozano, F.J., Waas, T., Lambrechts, W., Lukman, R., Huge, J. (2015). A review of commitment and implementation of sustainable development in higher education: results from a worldwide survey. Journal of Cleaner Production, 108, 1-18. 
Lozano, R., Lozano, F.J., Mulder, K., Huisingh, D., Waas, T. (2013a). Advancing higher education for sustainable development: international insights and critical reflections. Journal of Cleaner Production, 48, 3-9, http://dx.doi.org/10.1016/j.jclepro.2013.03.034.

Lozano, R., Lukman, R., Lozano, F.J., Huisingh, D., Lambrechts, W. (2013b). Declarations for sustainability in higher education: becoming better leaders, through addressing the university system. Journal of Cleaner Production, 48, 10-19, http://dx.doi.org/10.1016/j.jclepro.2011.10.006.

Marshall, S. (2007). Strategic Leadership of Change in Higher Education: What's New? Routledge.

Moore, J. (2005). Barriers and pathways to creating sustainability education programs: Policy rhetoric and reality. Environmental Education and Research, 11(5), 537-555.

Mintzberg, H. (1989). Mintzberg on management: Inside our strange world of organizations. Simon and Schuster.

Mintzberg, H. (2008). Tracking Strategy: Towards a General Theory of Strategy Formation. London: Oxford University Press.

Neville, D., Potvin, L., MacDonald, M., Williams, W., Pluye, P., Blair, L., Green, L. (2000). What are the key factors and processes associated with sustained environmental change supportive of health promotion? (NHRDP Grant \#6601-1216-94), St. John's, Newfoundland: Newfoundland and Labrador Center for Health Information.

NUS (National Union of Students) (2015). Student attitudes towards, and skills for sustainable development, https://www.heacademy.ac.uk/system/files/executive-summary-students.pdf (accessed 20 February 2019)

Orr, D. W. (2004). Earth in mind: On education, environment, and the human prospect. Washington, D.C.: Island Press.

Pappas, E., Pierrakos, O., Nagel, R. (2013). Using Bloom's taxonomy to teach sustainability in multiple contexts. Journal of Cleaner Production, 48, 54-64.

PRME (2018). The Principles for Responsible Management Education (PRME), http://www.unprme.org/resource-docs/PRMEBrochure2018.pdf (accessed 01 May 2019)

Quinn, J. B. (1980). Strategies for change: Logical incrementalism. Irwin Professional Publishing.

Ramos, T.B., Caeiro, S., van Hoof, B., Lozano, R., Huisingh, D., Ceulemans, K. (2015). Experiences from the implementation of sustainable development in higher education institutions: Environmental Management for Sustainable Universities. Journal of Cleaner Production, 106, 3-10.

Rampasso, I. S., Anholon, R., Silva, D., Ordoñez, R. C., Quelhas, O. L. G., Leal Filho, W., Santa-Eulália, L. A. (2018). An analysis of the difficulties associated to sustainability insertion in engineering education: Examples from HEIs in Brazil. Journal of Cleaner Production, 193, 363-371. 
Rittel, H. W. J., Webber, M. M. (1973). Dilemmas in a general theory of planning. Policy Sciences, 4(2), 155-169.

Roseland, M. (2000). Sustainable community development: integrating environmental, economic, and social objectives. Progress in Planning, 54(2), 73-132.

Rusinko, C. A. (2010). Integrating sustainability in higher education: a generic matrix. International Journal of Sustainability in Higher Education, 11(3), 250-259.

Ryan-Fogarty, Y., O’Carroll, D., O’Mahony, M.J., O’Regan, B. (2016). Development of the Green-Campus Programme in Ireland: Ensuring continuity of environmental education and action for sustainable development throughout the Irish Education System. In: Leal Filho, W., Pace, P. (Eds). Teaching education for sustainable development at university level. Switzerland: Springer International Publishing, 269-284.

Savelyeva, T., McKenna, J. R. (2011). Campus sustainability: emerging curricula models in higher education. International Journal of Sustainability in Higher Education, 12(1), 55-66.

Shiel, C. (2007). Developing and embedding global perspectives across the university. In: Marshall, S. (Ed.). Strategic Leadership of Change in Higher Education: What's New?. Routledge.

Shiel, C., Jones, D. (2016). Sustainability and social justice: Leadership challenges. In: Assembling and Governing the Higher Education Institution. Palgrave Macmillan, London, 11-34.

Sterling, S., Maxey, L. (2013). The sustainable university Taking it forward. The Sustainable University: Progress and Prospects, 2, 304.

Tippett, J., Handley, J. F., Ravetz, J. (2007). Meeting the challenges of sustainable development - A conceptual appraisal of a new methodology for participatory ecological planning. Progress in Planning, 67(1), 9-98.

Velazquez, L., Munguia, N., Platt, A., Taddei, J. (2006). Sustainable University: what can be the matter? Journal of Cleaner Production, 14(9-11), 810-819.

Watson, M. K., Lozano, R., Noyes, C., Rodgers, M. (2013). Assessing curricula contribution to sustainability more holistically: experiences from the integration of curricula assessment and students' perceptions at the Georgia Institute of Technology. Journal of Cleaner Production, 61, 106-116. http://dx.doi.org/10.1016/j.jclepro.2013.09.010.

Wright, T. S. A. (2006). Giving "teeth" to an environmental policy: a Delphi Study at Dalhousie University. Journal of Cleaner Production, 14(9-11), 761-768. https://doi.org/10.1016/j.jclepro.2005.12.007

Yanez, S., Uruburu, Á., Moreno, A., Lumbreras, J. (2018). The Sustainability Report as an essential tool for the holistic and strategic vision of Higher Education Institutions. Journal of Cleaner Production, https://doi.org/10.1016/j.jclepro.2018.09.171 


\begin{tabular}{|c|c|}
\hline $\begin{array}{l}\text { Ms. Ref. No.: JCLEPRO-D-19-02807R1 } \\
\text { Title: The Role of Planning in Implementing } \\
\text { Education Context }\end{array}$ & ustainable Development in a Higher \\
\hline Rebuttal Table & \\
\hline Associate Editor: & Responses \\
\hline $\begin{array}{l}\text { Thank you for re-submitting the above article } \\
\text { to the Journal of Cleaner Production. Please, } \\
\text { see additional comments below. }\end{array}$ & Thank you for your comment. \\
\hline $\begin{array}{l}\text { Given this, I would ask that you please } \\
\text { carefully check that all references are correct } \\
\text { and that there are no typographical errors. }\end{array}$ & $\begin{array}{l}\text { Thank you for your comment. All references } \\
\text { were checked. }\end{array}$ \\
\hline $\begin{array}{l}\text { Please, also pay attention to the quality of } \\
\text { figures and graphical abstract - the quality of } \\
\text { figures can be improved. }\end{array}$ & $\begin{array}{l}\text { Thank you for your comment. We tried to } \\
\text { improve the quality of all figures and of the } \\
\text { graphical abstract. }\end{array}$ \\
\hline $\begin{array}{l}\text { In addition, please ensure that the syntax } \\
\text { and grammar of the paper are correct, and } \\
\text { that the paper fully complies with the journal's } \\
\text { guidelines, including those relating to the } \\
\text { highlights. }\end{array}$ & $\begin{array}{l}\text { Thank you for your comment. The paper was } \\
\text { rechecked according to the guidelines and } \\
\text { the highlights were also adjusted. }\end{array}$ \\
\hline Reviewer \#2 & Responses \\
\hline $\begin{array}{l}\text { I commend the authors of this article on } \\
\text { making several edits to this version of the } \\
\text { manuscript that make it a much stronger } \\
\text { publication. The introduction remains a bit } \\
\text { overly detailed and difficult to follow. I would } \\
\text { encourage the authors to continue efforts to } \\
\text { make the introduction more concise, beyond } \\
\text { simply combining the first two subsections. }\end{array}$ & $\begin{array}{l}\text { Thank you for your comment. The } \\
\text { introduction was adjusted and we hope it is } \\
\text { now more concise. }\end{array}$ \\
\hline $\begin{array}{l}\text { The results are much more thorough and } \\
\text { now include information that is valuable to } \\
\text { the reader. }\end{array}$ & Thank you for your comment. \\
\hline
\end{tabular}




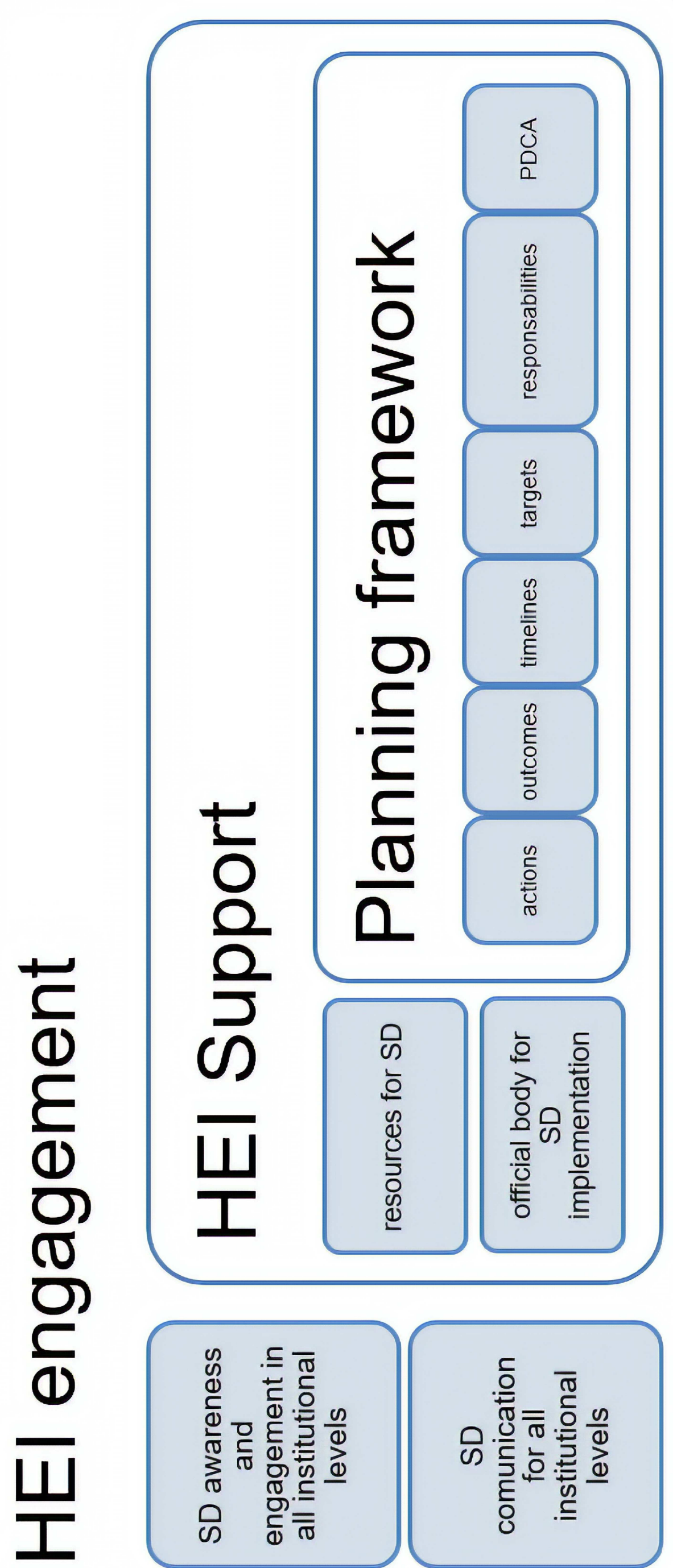




\section{Planning for SD}

\section{PURPOSE}

Appropriate Tools

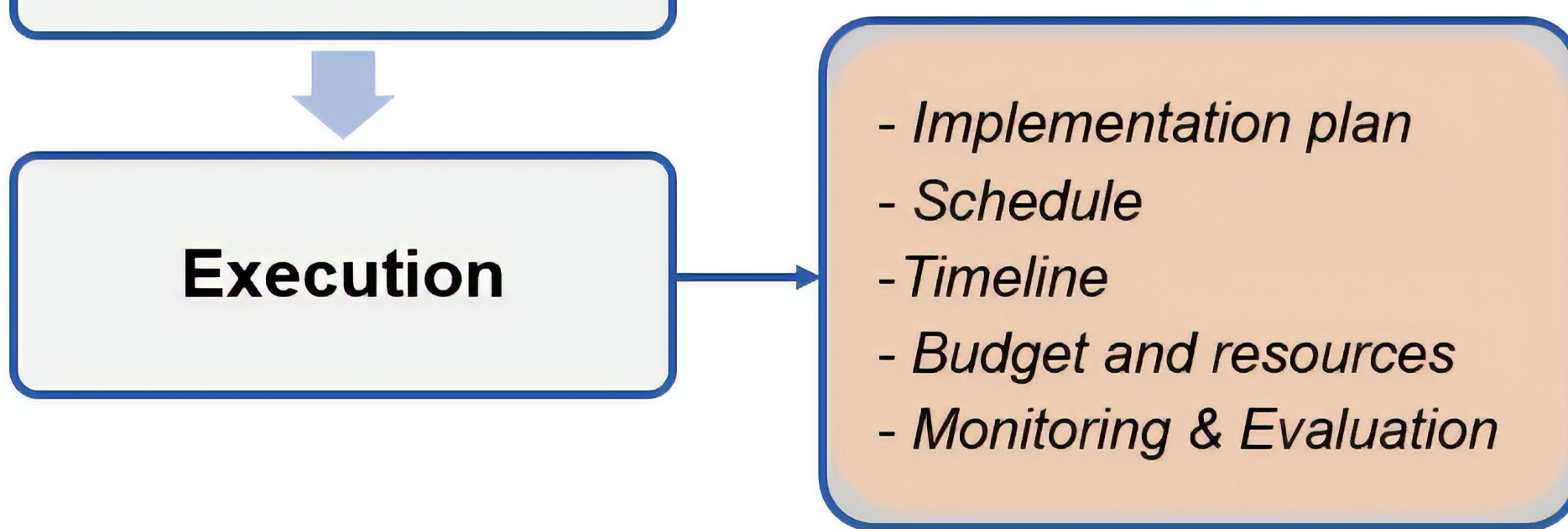




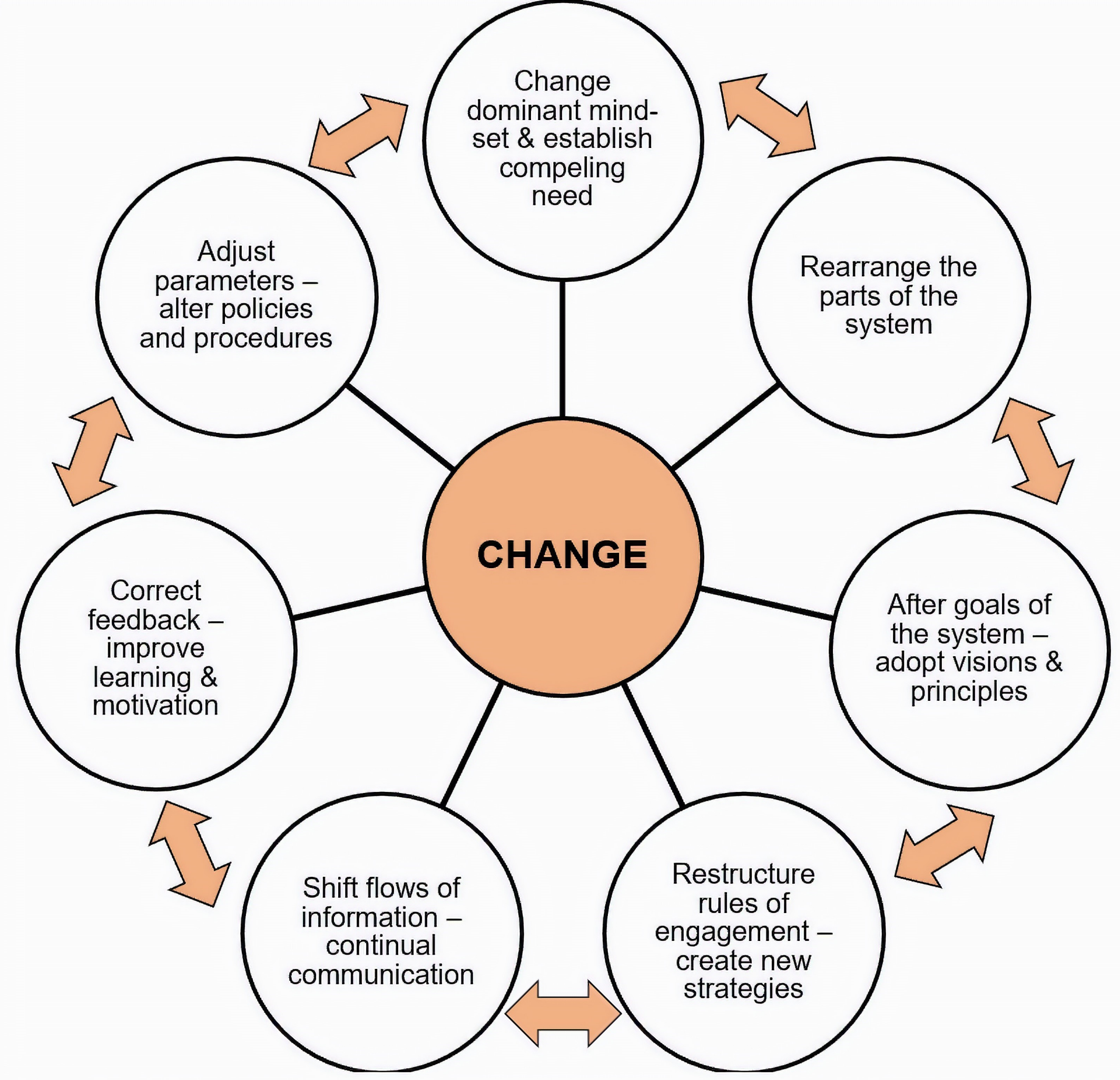




\section{HEl engagement}

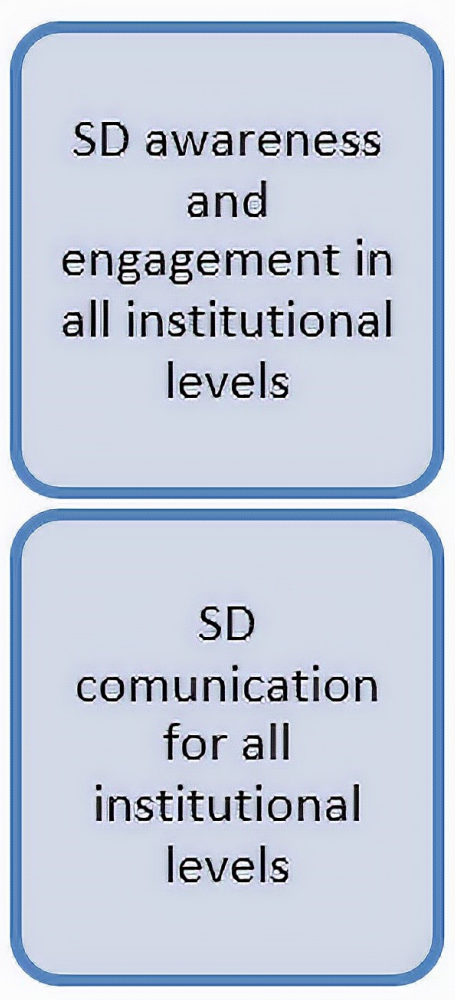

\section{HEI Support}

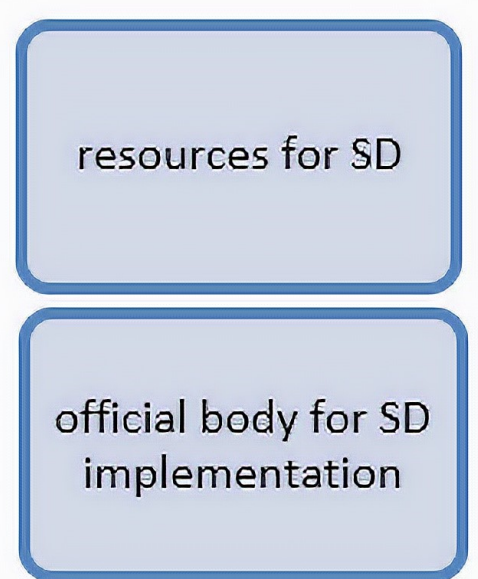

engagement in levels unication titutiona

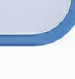

\section{Planning framework}

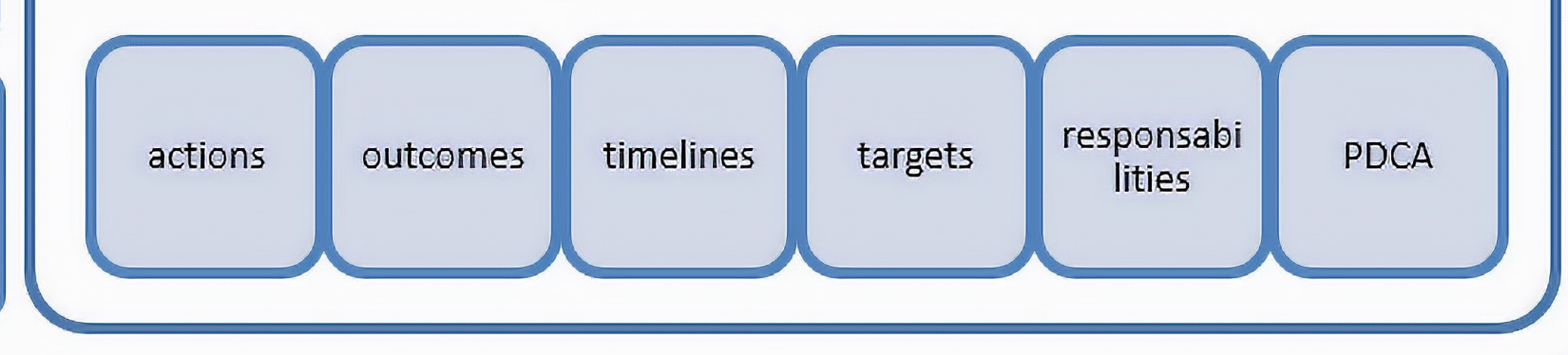

